\title{
Record of Pleopis schmackeri (Poppe) (Branchiopoda, Onychopoda) in the Guanabara Bay, Rio de Janeiro, Brazil
}

\author{
Andrea Marazzo ${ }^{1}$
}

\begin{abstract}
A first record of Pleopis schmackeri (Poppe, 1889) (Branchiopoda, Onychopoda) in the Guanabara Bay, Rio de Janeiro, Brazil is described. This marine cladoceran species occurred in zooplanktonic samples obtained on June 26, 2000, with densities $\cong 4.0$ ind. $\mathrm{m}^{-3}$. Its presence may be related with inflow of coastal waters to the bay.
\end{abstract}

KEY WORDS. Cladocera, Pleopis schmackeri, zooplankton, Guanabara Bay, Brazil

Cladocerans are small crustaceans that mainly inhabit fresh water, with only eight truly marine species (ONBÉ 1999). As compared with the rest of cladoceran species, the ecological characteristics of Pleopis schmackeri (Poppe, 1889) are unknown. This is probably due to its very rare presence and low abundance in temperate and tropical waters. Its occurrence has been described mainly in waters from the South China Sea through northern Honshu (Japan); and sporadic records from the Aqaba Bay (Red Sea) and Madagascar (Indian Ocean). According to these reports, $P$. schmackeri may be considered warm water, coastal and oceanic species. In Brazilian waters, a single record was made by RoCHA (1985) in the coastal waters of São Paulo (24⒉ $\left.27^{\prime} S-47^{\circ} 05^{\prime} \mathrm{W}\right)$, on $24^{\text {th }}$ June 1983.

The presence of $P$. schmackeri in the Guanabara Bay is an unexpected fact, because this cladoceran species had never been recorded before in spite of intense investigations in previous decades. This fact suggests that $P$. schmackeri does not participate in the zooplanktonic community of this bay. Guanabara Bay, Rio de Janeiro, southeastern Brazil $\left(22^{\circ} 41^{\prime}-23^{\circ} 56^{\prime} \mathrm{S}\right.$ and $\left.43^{\circ} 02^{\prime}-43^{\circ} 18^{\prime} \mathrm{W}\right)$, has been classified as a coastal estuary with shallow and partially mixed waters.

The occurrence of $P$. schmackeri was observed during research about the dynamics of planktonic communities of the Guanabara Bay. The zooplanktonic samples were obtained in surface water, at a fixed station on the entrance of the bay. In a time series of sampling (from February 2 to August 1, 2000 with 3-4 day intervals), P. schmackeri was detected only in the triplicate samples taken on June 26 , with mean densities $\cong 4.0$ ind. $\mathrm{m}^{-3}$. Water temperature and salinity were $21.6^{\circ} \mathrm{C}$ and 35.2 respectively. Population was composing by parthenogenetic females only. Mean body length and fecundity of individuals were $420 \mu \mathrm{m}$ and five embryos.female $^{-1}$ respectively. On that day, a strong intrusion of clearer and more saline

1) Laboratório de Zooplâncton, Departamento de Biologia Marinha, Instituto de Biologia, Universidade Federal do Rio de Janeiro. 21949-900 Rio de Janeiro, Rio de Janeiro, Brasil. E-mail: marazzo@biologia.ufrj.br 
oceanic waters was observed carrying several zooplanktonic species common in open ocean waters. It occurred probably due to approximation of the Brazil Current to the coast, as it is usual in the winter period (LUEDEMANN 1975). On account of these observations, and annual similarity with record performed by ROCHA (1985), it is suggested that $P$. schmackeri could be a common marine cladoceran species living in Brazilian coastal waters, and its may be recorded in neritic environments in winter, by influence of the Brazil Current displacement.

ACKNOWLEDGEMENTS. This research is part of PRONEX project, and it was supported by the Coordenadoria de Aperfeiçoamento de Pessoal de Ensino Superior (CAPES), Conselho Nacional de Desenvolvimento Científico e Tecnológico (CNPq) and Fundação de Amparo à Pesquisa do Estado do Rio de Janeiro (FAPERJ).

\section{REFERENCES}

LUEDEMANN, E.F. 1975. Contribuição ao estudo das correntes de superfície diante da costa leste brasileira (18³0'S-3840'W). Bol. Inst. Oceanogr., São Paulo, 24: 69-84.

ONBÉ, T. 1999. Ctenopoda and Onychopoda (= Cladocera), p. 797-813 In: D. BolTovsKoy (Ed.). South Atlantic Zooplankton. Leiden, Backhuys Publishers, 1705p.

RochA, C.E.F. DA. 1985. The occurrence of Pleopis schmackeri (Poppe) in the Southern Atlantic and other marine cladocerans on the Brazilian coast. Crustaceana 49 (2): 202-204.

Received in 30.XI.2001; accepted in 25.VI.2002. 